\title{
Storytelling Learning with Character Content Using Stimulus-Response Method
}

\author{
A. Anindyarini' ${ }^{1}$ F. Rokhman ${ }^{2}$, M. Mulyani ${ }^{3}$, Andayani $^{4}$ \\ ${ }^{1,2}$ Doctoral Program of Language Education Studies, Graduate School, Universitas Negeri Semarang, Indonesia, \\ ${ }^{3,4}$ Indonesian Language Education Study Program, Faculty of Teacher Training and Education, USM, Indonesia \\ ${ }^{1}$ Corresponding email: atikahanindyarini@gmail.com
}

\begin{abstract}
This article aimed to describe (1) the problem the students encounter in storytelling learning, (2) the teachers' way of motivating students in storytelling. This study was a descriptive study. Data of research was collected through interview and distributing questionnaire to teachers and students in SMP 14, SMP 19, SMP Al Islam, and SMP Al Abidin. The research was conducted for 1 year, from June 2017 to June 2018. The result of research showed that the problem the students encounter in storytelling learning was related to their low selfconfidence in storytelling. The problem was solved, among others, by applying storytelling learning with stimulus-response method. Stimulus-response practice in storytelling was conducted by means of giving stimulus and response to friends who were telling a story. It was intended to motivate their friend in order to tell story confidently, to remind the friends when content, diction, proficiency, intonation, spelling and expression were not as expected. In story telling learning practice, the character of students was expected to grow and develop.
\end{abstract}

Keywords: Self-confidence, Storytelling, Stimulus, Response, and Character

\section{Introduction}

There is a sentence stating that "the number of children is only 25 percents of total population but it determines 100 percents of the nation's future". It means that whether a nation is developed is highly dependent on the quality of its young generation (Megawangi, 2007:57). Thus, a nation's quality is determined by its young generation's quality. We no longer need to rely on an assumption that three basic capitals of a nation's advance are: wide area, abundant natural resource, and large number of populations. Indonesia has all of them. However, compared with other nations' advance such as Singapore not having the three criteria, Indonesia is less advanced compared with Singapore. Therefore, Singapore is considered as a very developed state. Fukuyama (in Megawangi, 2007: 58) stated that a developed is the nation with social capital, high trust society. It is characterized with a community within which the individuals are trustable or have good character.

Character is defined as "mental or moral quality, moral power, name, or reputation (Hornby and Parnwell in Hidayatullah, 2010:15). Furthermore, Megawangi (2007:83) stated that the important component to consider in character education is how to grow the will to do good deed. It originates from the love to doing good deed. This love aspect is a source of energy enabling an individual to have consistent character.

Speaking of character building is inseparable from how to create individuals' personality earlier in house and school environment. Child character education at home, of course, becomes parents' responsibility, while child character education at school becomes teachers and headmasters' responsibility. Education emphasizing on cognitive aspect of child only regardless emotional and spiritual aspects will result in disadvantage.

School should teach character education that can educate child's emotion. Through character education, child is accustomed to appreciate friends, to care about each other, and to have commitment to be the best one (according to capacity), without thinking of how to defeat and to fall down friends. Such class or school circumstance can make students glad with their school climate, thereby making them receive lesson easily and learning joyfully (Megawangi, 2007:129).

Regarding this, Lickona (2008:170) explained that in character education, teacher should design an effective unit or lesson related to moral values. It can be accomplished, among others, by means of choosing good materials.

Story is one of favorite instruments the world-class teachers choose to be the learning material. Storytelling is the method of teaching with appeal rather than compulsion, as story is 
inviting rather than compelling in nature. Story frames imagination and touches heart. The power of a good story can provoke feeling. That is why storytelling is a natural way of engaging and building emotional aspect of a child's character (Lickona 2008:79).

Storytelling is a favorite learning to children. Storytelling is a series of systematic strategies containing activity of transferring story from storyteller to listeners. Storytelling is a natural art before being a skill. Storytelling ability can be developed through genuine practice (Subyantoro, 2013:34).

However, despite the use of good materials, the probability of failure in giving value education remains to exist. Therefore, a teacher needs an effective teaching strategy that can stimulate students to utilize material and to think of it seriously (Lickona 2008: 172). To explore moral value, in addition to choosing an appropriate material, teacher should also be able to choose an effective strategy to teach it.

Relevant to the statement, in storytelling learning, there are still some problems to be solved. Therefore, this article describes the problems the students encounter in storytelling learning at school and the teachers' way of motivating the students in storytelling learning

\section{Method}

This study was a descriptive research. Data of research was collected through interview and distributing questionnaire to teachers and students in 4 junior high schools (SMP 14, SMP 19, SMP Al Islam and SMP Al Abidin). The research was conducted for 1 year, from June 2017 to June 2018. To obtain valid data, data validation was conducted using source and method triangulation techniques. Technique of analyzing data used in this study was an interactive model of analysis (Miles and Huberman 1994: 10). Interactive analysis mechanism basically involved three components of analysis: data reduction, data display, and verification.

\section{Result and Discussion}

\subsection{Students' Problems in Storytelling}

The data obtained through distributing questionnaire shows that $83.33 \%$ teachers state that the difficulty the student have in fantasy story learning is that of retelling the fantasy story orally before the class. Not all students have selfconfidence so that some students are still afraid of speaking before the class.
The problem the students encounter during storytelling is relevant to the result of interview with the following teachers. SHR, DW, SKN, DT, IND, and FTM stated that the constraints the students encountered during telling story orally is their poor self-confidence. Teacher should improve the students' self-confidence.

The students' poor self confidence can also be seen from the result of interview with Izz and ANT. When given an opportunity to tell a story, IZZ actually feel glad, but sometimes he forgets and finds idea of story difficultly during telling story before the class. In addition, IZZ also feels nervous or less self-confident as he memorizes the story poorly and practices inadequately. Other students do similarly. ANT admits that he is very glad to be given an opportunity to retell a fantasy story. However, he feels that his heart beats rapidly when she should perform before the class. It will affect his performance and he will memorize the story difficultly.

It is in line with Chaniago (2011:121) and Morgan and Schmit (2012:16) suggesting about students' anxiety in speaking. This speaking anxiety is encountered by individual by showing off rapid heart beat, nervousness, cold sweating, and as a result they can speak nothing. Still regarding this, Bodie in Morgan and Schmit (2012:16) stated that anxiety encountered in communication in learning language can attenuate and affect students' adaptation to the end objective of learning. Meanwhile, according to them, public speaking competency is very important to support the students' successful learning both inside and outside class.

Kelly in Morgan and Schmit (2012:16) said that a technique that can be used to reduce public speaking anxiety is skill practicing. This practice is targeted to improve individual's language behavior. It is relevant to Bishop and Kimball (2006:28-31) explaining that many adults in society fear for speaking before the public. It is because of inadequate speaking habituation/practice before the public. On the contrary, when children and adolescents are accustomed to be engaged in oral presentation, they will speak before the public more comfortably in adulthood. Storytelling can help encourage an individual's self confidence and composure (Caulfield 2000, Hamilton \& Weiss 1990, Nano-Bednar 1998).

The problem of students can be seen from the data showing that $100 \%$ teachers feel that there is a problem or difficulty in oral storytelling practice conducted by students, 
particularly in the term of self-confidence. In addition to poor self-confidence, according to teachers (TWA and THW), students' preparation is less maximal. This data is relevant to teachers' reply stating that speaking skill to students individually is the skill implemented rarely by teacher. It is because of limited time allocation and so many students in the class, leading to the difficulty to implement it. In addition, Hidayat in Muamamar (2008:318) explained that language skill is practiced more in reading and writing skills. Therefore, listening and speaking skills are often neglected.

The actual condition proves this statement. In the class, teachers not always implement the learning according to basic competency the students should achieve. For example, in speaking skill teacher sometimes does not give the students the opportunity of practicing speaking but tells them to write and to read only.

\subsection{How Teacher Motivates Students in Storytelling}

Teachers have used some methods to solve the problem of poor self-confidence so far. Some teachers try to approach the students intensively to be willing to tell story (THW), some others give storytelling model, and some others stimulate students by giving added value (NPW), and some teachers hold discussion activity to practice their speaking or storytelling skill.

Meanwhile, DW attempts to stimulate the students by telling them to retell the chronology of their activity from waking up to going to school. Finally, the students can tell a story and the result is better because they tell their own experience. It makes the circumstance more alive because he is more expressive. The student's mark is also better as he is communicative (DW). It is a way the teacher can use to stimulate the students to speak.

To improve the students' self-confidence in storytelling, some teachers organize storytelling learning in group. The result of interview shows that more students prefer practicing storytelling in group to individually. They state that practicing storytelling in group makes them more self-confident and can help each other when they find difficulty.

A student (IZZ) said that teacher gives the students the opportunity of telling story in group more frequently than individually, and a group consists of four students. $\mathrm{He}$ feels selfconfidently when practicing telling story in a group. So far, teachers have divided story in group by text structure (orientation, complication, and resolution), but some teachers have applied chain story, and some others divide the story by character.

Stimulus-response practice in storytelling is implemented with stimulus-response-based cooperative method, by giving stimulus and response each other to friends who are practicing storytelling. Stimulus-response strategy is chosen because it is an effective strategy to apply in speaking skill. It is confirmed by Iskandarwassid and Sunendar (2008:240) stating that speaking learning strategy refers to stimulus-response principle. As long as the speaker masters these two variables, he/she can be categorized as having speaking learning ability.

Stimulus-response theory is the one attempting to establish as much as possible stimulus-response relation. Uno (2011:194) explains that unconsciously a series of stimulusresponse occurs in skill learning activity. In learning a skill, movements are improved through practices guided by a skill program. That is why this learning based on theoretical approach requires teachers to communicate the program to students, to analyze skill in its components, to diagnose students' performance, and to guide the students' practice.

In relation to stimulus, Sagala (2007:42) explains that anyone masters stimulus-response as much as possible is the smart one or the one successful in learning. The establishment of stimulus-response relation is conducted through repetition. Suprijono (2011: 10) explains that learning with stimulus-response is a reciprocal learning activity. This type is related to the students' behavior consciously responding appropriately to the stimulation in learning situation.

Stimulus-response practice in storytelling learning with cooperative method is conducted by means of giving stimulus and response each other to friends who are telling story. Students can give some stimuli to other students by giving memorable clue to other students (partners can remind each other when one of them forgets the story), correcting when some dictions are inappropriate, giving signals aiming to motivate their friends to be more selfconfident during storytelling, reminding when their partner's content, diction, proficiency, intonation, spelling, and expression are not as expected. 
For the students to give stimulus and response more actively and enthusiastically to their partner, the students' attitude in storytelling practicing process will be assessed by their partner. The attitude assessment includes the attitude of appreciating achievement, social concern, friendliness, and polite language. This assessment on attitude between friends is expected to grow and to develop the students' character.

In addition to the students' stimulus, teachers' stimulus is of course needed by students. Gaffur (in Majid 2013: 288) suggested that in the learning process, teachers should be able to make their students active. To grow students' activity, stimuli can be given in the form of debriefing, discussion, practice and exercise, and assignment.

Learning process, according to Dick and Carey (1978:108), will run more successfully when students actively practice directly and relevantly to the specified objective of learning. The points the teachers should consider are: (1) giving the students the opportunity of their practicing knowledge, attitude, or skill and (2) giving feedback to the students' learning outcome.

Through feedback the teachers have given, students will find out immediately whether or not the activity they do is correct, appropriate, or still needs improvement (Uno 2011: 6). Feedback can be either positive or negative reinforcement. Through positive reinforcement (good, excellent, very appropriate, and etc), the behavior is expected to be maintained or demonstrated by students. Otherwise, through negative reinforcement (less appropriate, incorrect, need perfection, and etc), the behavior is expected to be removed or the students will not do similar error. The opportunity of practicing and the presence of feedback from students and teachers help students solve problems related to their' inadequate preparation in storytelling practice.

This storytelling is also associated with character education because storytelling learning is considered as an effective way of educating the students' character. To produces human beings with good character, character education is needed. Through fantasy story, students are expected to take moral values from a story in order to grow and to develop their character. In addition to through story content, character of students can be grown and developed when they practice telling story using stimulus-response method. Through storytelling practice, some characters can be grown and developed such as attitude of appreciating achievement, social concern, friendliness, and polite language.

\section{Conclusion}

\section{The problems the students encounter in oral storytelling are poor self-confidence, inadequate bravery, nervousness, poor speaking ability, and inadequate preparation in practicing.}

Students' inadequate preparation in practicing is consistent with teachers' reply stating that speaking skill to students individually is the skill implemented rarely by teacher. It is because of limited time allocation and so many students in the class, leading to the difficulty to implement it.

Stimulus-response practice in storytelling learning is implemented with stimulus-response method, by giving stimulus and response each other to friends who are practicing storytelling. Stimulus-response strategy is chosen because it is an effective strategy to apply in speaking skill.

Thus, to improve the students' speaking skill particularly storytelling skill, it is very appropriate to apply this stimulus-response strategy in the learning. Teacher should be able to stimulate students to be willing to tell story, to give the students the opportunity of practicing storytelling, and to motivate the students give stimulus and response to other students during storytelling.

\section{References}

Bishop, Kay; Kimball, Melanie A. Apr 2006. "Engaging Students in storytelling" Teacher Librarian 33. 4: 28-31. Retrieved on January 12, 2013.

Chaniago, Sam Mukhtar, Jamaludin Badusa, Mohamed Amin Embi. 2011. "Teaching Problem In Language Skills At Indonesian School".Malay Language Education Journal (MyLEJ). Retrieved on January 10, 2011.

Dick and Carey. 1978. The Systemic Design of Instruction. New York: Longman.

Hidayatullah, Furqon. 2010. Pendidikan Karakter: Membangun Peradaban Bangsa. Surakarta:Yuma Pustaka.

Iskandarwassid dan Sunendar .2008. Strategi Pembelajaran Bahasa. Bandung: Kerjasama antara Sekolah Pascasarjana Universitas Pendidikan Indonesia dan PT Remaja Rosdakarya.p. 240

Lickona, Thomas. 2008. Educating for 
Character : How Our Schools Can Teach Respect and Resposibility. New York:Bantam Book.

Majid, Abdul. 2013. Strategi Pembelajaran. Bandung: Remaja Rosdakarya.

Megawangi, Ratna. 2007. Semua Berakar pada Karakter. Jakarta: Fakultas Ekonomi Universitas Indonesia.

Miles, M. \& Huberman,B.1984. Qualitative Data Analysis. Beverly Hills-Sage Publisher.

Morgan, Tony Docan and Tomas Schmit. 2012. "Reducing Public Speaking, Anxiety for Nativeand Non-Native English Speakers: The Value of Systematic Desensitization, Cognitive Restructuring, and Skills Traning"Cross Cultural Communications. Vol 8, no 5, 2012,pp 16-19.ISSN 1923.6700 (online). www.cscanada.net.
Muammar. 2008. "Pembelajaran Berbicara yang Terabaikan pada Mata Pelajaran Bahasa Indonesia Sekolah Dasar". In Anwar Efendi (ed). Bahasa dan Sastra dalam Berbagai Perspektif. Yogyakarta: Kerjasama Fakultas Bahasa dan Seni Universitas dengan Penerbit Tiara Wacana.

Sagala, Syaiful. 2007. Konsep dan Makna Pembelajaran. Bandung: Alfabeta.

Subyantoro. 2013. Pembelajaran Bercerita: Model Bercerita untuk Meningkatkan Kepekaan Emosi dalam Berapresiasi Sastra. Yogyakarta: Ombak.

Suprijono, Agus. 2011. Cooperative Learning : Teori dan Aplikasi Paikem. Yogyakarta: Pustaka Pelajar.

Uno, Hamzah B. 2009. Perencanaan Pembelajaran. Jakarta: PT Bumi Aksara. 